\title{
Modified protocol of omalizumab treatment to prevent carboplatin-induced drug hypersensitivity reactions: a case study
}

Hanneke N. G. Oude Elberink ${ }^{1,2,3}$, Mathilde Jalving ${ }^{1,2,3}$, Hilda Dijkstra ${ }^{1,2,3}$ and Annick A. J. M. van de Ven ${ }^{1,2,3^{*}}$ (1)

\begin{abstract}
Carboplatin administration can usually be safely continued via a so-called desensitisation protocol when hypersensitivity reactions arise. Severe break-through reactions that occur early during desensitisation are likely to be lgE-mediated; in that case, addition of omalizumab premedication should be strongly considered.
\end{abstract}

Keywords: Carboplatin, Desensitisation, Drug hypersensitivity, Omalizumab

\section{To the editor}

Platinum-based chemotherapy is the cornerstone in the treatment of various solid tumours, including gynaecologic malignancies. The incidence of drug hypersensitivity reactions (DHRs) is high; up to $12 \%$ for carboplatin in gynaecological tumours [1]. The pathogenesis of platinrelated DHRs may vary but for carboplatin, IgE-specific basophil activation has been demonstrated [2].

Fortunately, patients with a DHR to carboplatin can generally still be safely treated with carboplatin using a desensitisation protocol [3]. Protocols rely on two main principles, namely gradually increasing the dose of drug and using a premedication consisting of a combination of H1-, H2-antihistamines, corticosteroids and in some cases a leukotriene antagonist [3]. This method is successful for most patients; however, some still suffer from symptoms despite intense pre-treatment and extra antiallergy medication during the desensitisation procedure. We describe a patient who developed a systemic allergic reaction at the first step (1 mg carboplatin/hour) of the desensitisation schedule on two separate occasions.

\footnotetext{
*Correspondence: a.a.j.m.van.de.ven@umcg.nl

1 Department of Allergology and Internal Medicine, Internal address

code AA21, University Medical Center Groningen, Hanzeplein 1, 9713 GZ Groningen, The Netherlands

Full list of author information is available at the end of the article
}

Carboplatin treatment could, however, be successfully continued after pre-treatment with omalizumab and no further adverse events occurred.

The case concerns a now 57 -year-old woman diagnosed with stage III ovarian cancer of the endometrioid type in 2008 (Table 1). In 2014, she had a platinum-sensitive relapse without rational surgical options and palliative chemotherapy with carboplatin/paclitaxel was initiated. During the second cycle, she developed an allergic reaction consisting of patchy erythema, coughing, throat and chest discomfort. The chemotherapy was stopped and referral to an allergologist followed. Carboplatin hypersensitivity was diagnosed based on the clinical presentation in combination with skin tests positive for carboplatin (Table 2). Three subsequent cycles of carboplatin were given according to a 10-step desensitisation schedule and were uneventful. (Figure 1a).

The desensitisation procedure was successfully repeated with a relapse 3 years later. In 2018, carboplatin monotherapy was initiated due to a third symptomatic platinum-sensitive relapse. During the first cycle, an allergic reaction occurred at the last desensitisation step (Fig. 1b). The reaction consisted of flushing, pruritus and erythema of the face and chest. The carboplatin infused was stopped and intravenous clemastine was administered resulting in resolution of symptoms

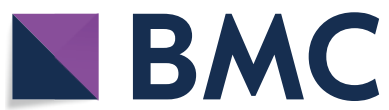

(c) The Author(s) 2020. This article is licensed under a Creative Commons Attribution 4.0 International License, which permits use, sharing, adaptation, distribution and reproduction in any medium or format, as long as you give appropriate credit to the original author(s) and the source, provide a link to the Creative Commons licence, and indicate if changes were made. The images or other third party material in this article are included in the article's Creative Commons licence, unless indicated otherwise in a credit line to the material. If material is not included in the article's Creative Commons licence and your intended use is not permitted by statutory regulation or exceeds the permitted use, you will need to obtain permission directly from the copyright holder. To view a copy of this licence, visit http://creativeco mmons.org/licenses/by/4.0/. The Creative Commons Public Domain Dedication waiver (http://creativecommons.org/publicdomain/ zero/1.0/) applies to the data made available in this article, unless otherwise stated in a credit line to the data. 
Table 1 Summary of clinical events and treatment over time

\begin{tabular}{|c|c|c|c|c|}
\hline Year & Event & Surgical debulking & Adjuvant chemotherapy & Allergology \\
\hline 2008 & $\begin{array}{l}\text { Stage III ovarian cancer of the endometri- } \\
\text { oid type }\end{array}$ & Yes & 6 Cycles of carboplatin and paclitaxel & \\
\hline \multicolumn{5}{|l|}{2009} \\
\hline 2010 & Disease relapse & Yes & No & \\
\hline \multicolumn{5}{|l|}{2011} \\
\hline \multicolumn{5}{|l|}{2012} \\
\hline 2013 & Disease relapse & Yes & No & \\
\hline 2014 & $\begin{array}{l}\text { Symptomatic platinum-sensitive disease } \\
\text { relapse }\end{array}$ & Not possible & $\begin{array}{l}2 \text { Cycles of carboplatin/paclitaxel } \\
\text { Cycle } 3 \text { omitted } \\
\text { Cycle } 4-6 \text { according to 10-step desensiti- } \\
\text { sation schedule }\end{array}$ & $\begin{array}{l}\text { Cycle 2: allergic reaction } \\
\text { Skin tests positive for carbopl- } \\
\text { atin, negative for paclitaxel }\end{array}$ \\
\hline \multicolumn{5}{|l|}{2015} \\
\hline \multicolumn{5}{|l|}{2016} \\
\hline 2017 & $\begin{array}{l}\text { Symptomatic platinum-sensitive disease } \\
\text { relapse }\end{array}$ & No & $\begin{array}{l}6 \text { Cycles of carboplatin/paclitaxel accord- } \\
\text { ing to 10-step desensitisation schedule }\end{array}$ & Skin tests positive for carboplatin \\
\hline 2018 & $\begin{array}{l}\text { Symptomatic platinum-sensitive disease } \\
\text { relapse }\end{array}$ & No & $\begin{array}{l}6 \text { Cycles of carboplatin monotherapy } \\
\text { according to 10-step desensitisation } \\
\text { schedule with additional omalizumab } \\
\text { for cycle 4-6 }\end{array}$ & $\begin{array}{l}\text { Cycle 1: flushing, pruritus and } \\
\text { erythema of the face and chest } \\
\text { Cycle } 2+3 \text { : Anaphylaxis } \\
\text { Skin tests positive for carboplatin } \\
\text { (negative for cisplatin) } \\
\text { Cycle 4-6: Uneventful } \\
\text { Skin tests persistently positive }\end{array}$ \\
\hline 2019 & $\begin{array}{l}\text { Symptomatic platinum-sensitive disease } \\
\text { relapse }\end{array}$ & No & $\begin{array}{l}6 \text { Cycles of carboplatin monotherapy } \\
\text { according to 10-step desensitisation } \\
\text { schedule with additional omalizumab }\end{array}$ & No events \\
\hline
\end{tabular}

Table 2 Diagnostic testing in suspected carboplatin allergy

\begin{tabular}{|c|c|c|c|c|}
\hline Time after initial diagnosis (years) & 6.5 & 9.5 & 11 & 11.2 \\
\hline Status & $\begin{array}{l}\text { Prior to } 2 \text { nd series of } \\
\text { carboplatin/pacli- } \\
\text { taxel }\end{array}$ & $\begin{array}{l}\text { Prior to 3rd series of } \\
\text { carboplatin/pacli- } \\
\text { taxel }\end{array}$ & $\begin{array}{l}\text { After } 3 \text { cycles carboplatin } \\
\text { monotherapy (4th series), 0x } \\
\text { omalizumab }\end{array}$ & $\begin{array}{l}\text { After } 6 \text { cycles carboplatin } \\
\text { (4th series) and } 4 x \text { omali- } \\
\text { zumab** }\end{array}$ \\
\hline Saline, diameter (mm) & 0 & 0 & 0 & 0 \\
\hline Histamine, diameter (mm) & 9.5 & 4 & 7.5 & 6 \\
\hline \multicolumn{5}{|l|}{ Drugs tested: diameter of wheal in $\mathrm{mm}$} \\
\hline Carboplatin 0.01 mg/ml & 8.5 & 0 & 6 & 0 \\
\hline Carboplatin $0.1 \mathrm{mg} / \mathrm{ml}$ & N/A & 0 & 7 & 6.5 \\
\hline Carboplatin $1 \mathrm{mg} / \mathrm{ml}$ & N/A & 4.5 & 7.5 & 5.5 \\
\hline Paclitaxel $0.001 \mathrm{mg} / \mathrm{ml}$ & 0 & N/A & N/A & N/A \\
\hline Paclitaxel $0.01 \mathrm{mg} / \mathrm{ml}$ & 0 & N/A & $\mathrm{N} / \mathrm{A}$ & $\mathrm{N} / \mathrm{A}$ \\
\hline Paclitaxel $0.1 \mathrm{mg} / \mathrm{ml}$ & 0 & N/A & N/A & N/A \\
\hline Paclitaxel $1 \mathrm{mg} / \mathrm{ml}$ & 0 & N/A & N/A & N/A \\
\hline Cisplatin $0.01 \mathrm{mg} / \mathrm{ml}$ & N/A & N/A & 0 & 0 \\
\hline Cisplatin 0.1 mg/ml & N/A & N/A & 0 & 0 \\
\hline Cisplatin $1 \mathrm{mg} / \mathrm{ml}$ & N/A & N/A & 0 & 0 \\
\hline
\end{tabular}

Overview of intracutaneous testing for carboplatin and other chemotherapeutics. Positive results are shown in italics. Diameter $=$ average of the length and width of the wheal, read 15-20 min after intracutaneous injection of the drug

$N / A$ not assessed

* Skin tests were performed 8 weeks after the last omalizumab injection 

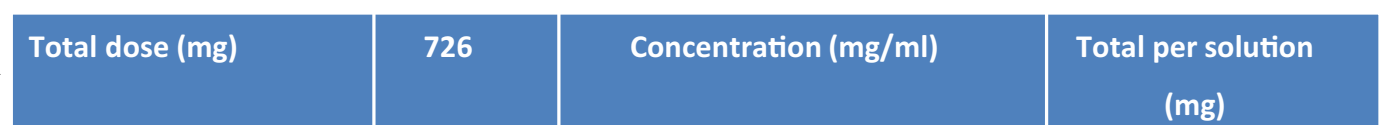

\begin{tabular}{|l|}
\hline Solution A \\
\hline Solution B \\
\hline
\end{tabular}

$100 \mathrm{ml}$

0.5

50

Solution C

$100 \mathrm{ml}$

0.726

72.6

Step

$150 \mathrm{ml}$

4.84

726

Step

Solution

Rate

Time

Administered

Cumulative dose

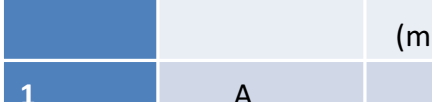

\begin{tabular}{|l|l|}
\hline 1 & A \\
\hline 2 & A \\
\hline
\end{tabular}

$(\mathrm{ml} / \mathrm{min})$

(min)

dose (mg)

(mg)

15

0.250

0.250

$3 \quad A$

5

15

0.625

0.875

$4 \quad A$

5 B

B

7

\begin{tabular}{|l|l|}
\hline 8 & $C$ \\
\hline 9 & $C$ \\
\hline 10 & $C$ \\
\hline
\end{tabular}

$A$
$A$

\begin{tabular}{l|l}
$10 \quad 15$ \\
\hline
\end{tabular}

1.250

2.125

\begin{tabular}{l|l}
\hline 15 & 2.500 \\
\hline
\end{tabular}

4.625

20

\begin{tabular}{l|l}
20 & 15
\end{tabular}

\begin{tabular}{l|l}
15 & 3.630 \\
\hline
\end{tabular}

8.255

\begin{tabular}{l|l}
15 & 7.260
\end{tabular}

15.515

C 20

\begin{tabular}{|l|l|}
\hline 40 & 15 \\
\hline 20 & 15 \\
\hline
\end{tabular}

24.2

39.7

40

15

48.4

88.1

\begin{tabular}{l|l} 
C & 80
\end{tabular}

15

96.8

184.9

100

67

541.1

726.0
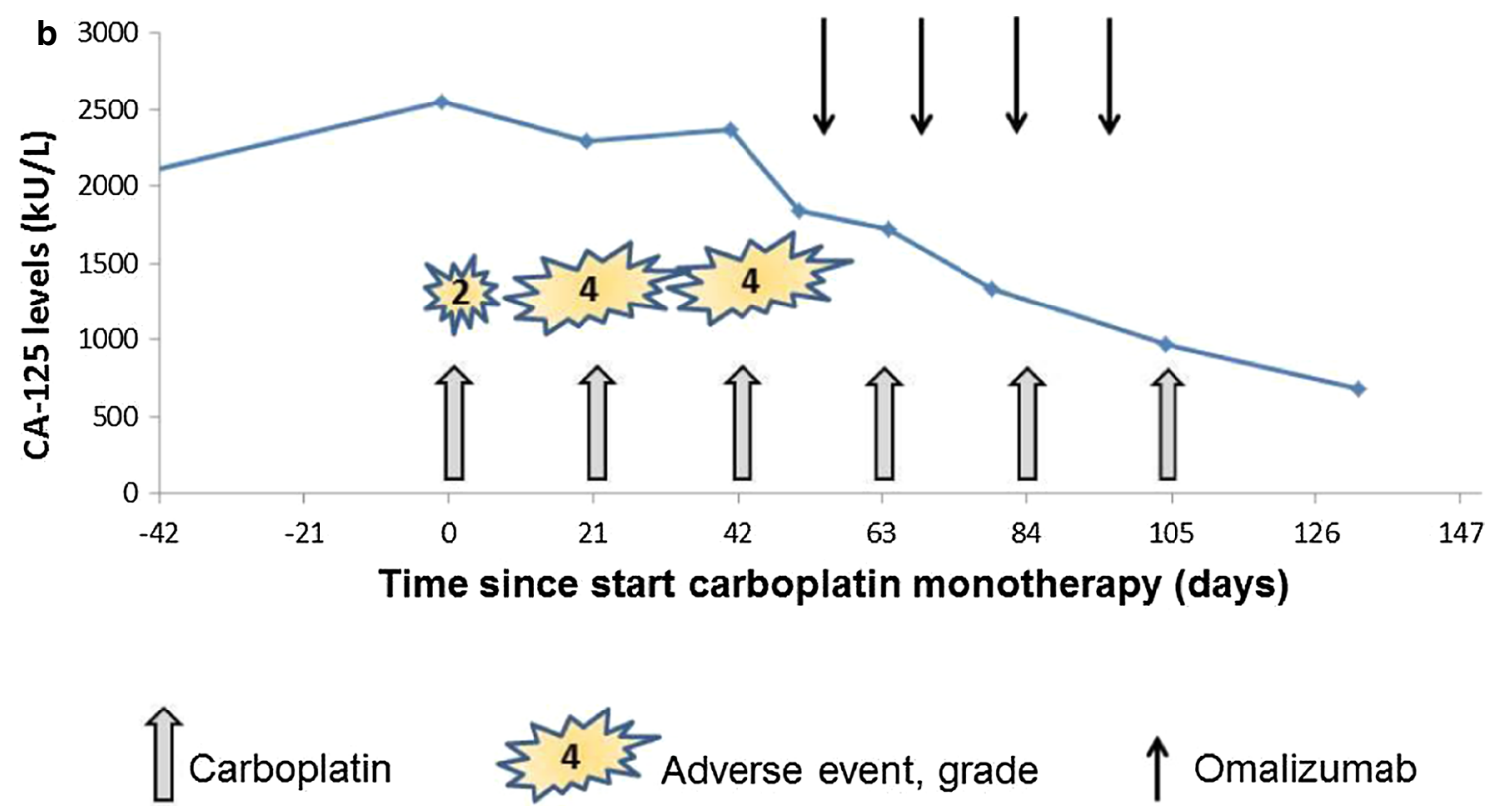

Fig. 1 Management of carboplatin allergy. a 10-step desensitisation schedule for carboplatin. Cumulative dose as administered in the 6th and last cycle of the course. $\mathbf{b}$ Overview of carboplatin and omalizumab administration in relation to the adverse allergic reactions

within minutes. The desensitisation was successfully continued at the penultimate infusion rate. 3 weeks later she experienced a more severe reaction moments after commencing the first infusion step, despite pre-treatment with $\mathrm{H} 1 / \mathrm{H} 2$-antihistamines and dexamethasone. She had symptoms of flushing, hypotension, dyspnoea 
with chest discomfort, throat tightness and abdominal discomfort. Additional administration of clemastine, ranitidine and dexamethasone had insufficient effect and $0.5 \mathrm{mg}$ of intramuscular epinephrine was required to relieve symptoms. There was no alternative explanation for this reaction, i.e. no co-factors such as concurrent infection, recent exercise or use of novel medications. After administration of the abovementioned medication, the desensitisation could be continued according to protocol without further additional medication or adverse events. During administration of the third cycle, despite optimizing premedication $(20 \mathrm{mg}$ dexamethasone i.v., $50 \mathrm{mg}$ ranitidine i.v., $2 \mathrm{mg}$ clemastine i.v. and $10 \mathrm{mg}$ montelukast orally, all $\geq 1 \mathrm{~h}$ prior to the first infusion), a similar anaphylactic reaction occurred at the first infusion step. Intramuscular epinephrine halted the allergic reaction and again, the desensitisation could be completed without other events.

Since further dilution of the carboplatin to allow an even slower desensitisation was not possible (in accordance to the SmPC of Carboplatin), other potential solutions were explored. Ojaimi et al. [4] described a patient who failed their 2-day and subsequently 4-day desensitisation protocol for carboplatin. After 3 fortnightly doses of $300 \mathrm{mg}$ of omalizumab, a monoclonal anti-IgE antibody, carboplatin was successfully administered over 4 days.

We opted to aim to reduce the burden of anti-carboplatin IgE-antibodies by administering omalizumab. Our patient received one dose of omalizumab $300 \mathrm{mg}$ 2 weeks before the 4th cycle of carboplatin was administered, and continued fortnightly (Fig. 1b). The following three administrations of carboplatin occurred without any side effects and no adaptations to the desensitisation protocol were required. Omalizumab was well tolerated. She had a good clinical and partial radiological response to the chemotherapy with $73 \%$ decreased CA-125 titres and commenced maintenance treatment with niraparib 6 weeks after the last cycle of chemotherapy. Unfortunately, she relapsed within 6 months and carboplatin monotherapy was reinitiated. The anti-allergy premedication regimen included omalizumab $300 \mathrm{mg}$ every 14 days (first injection was given 11 days prior to the first cycle) and the desensitisation procedure was carried out uneventfully.

We here describe the successful addition of omalizumab to the conventional anti-allergic medication in a patient with severe break-through allergic reactions to carboplatin despite an optimized desensitisation schedule. To our knowledge, this is the second time omalizumab has been used as an adjuvant during carboplatin desensitisation. Ojaimi and colleagues added omalizumab to a more conservative desensitisation protocol.
Our results confirm their findings and suggest that one dose of omalizumab prior to the start of desensitisation may already be sufficient, thereby minimizing treatment delay and enabling desensitisation procedures to be kept at the regular time schedule of $3.5 \mathrm{~h}$.

There is limited but growing experience using omalizumab for desensitisation of DHR; case-reports or small case series describe positive results for aspirin [5], insulin [6], Elosulfase A, [7] and recently oxaliplatin [8]. Careful selection of patients remains pivotal and sufficient knowledge regarding the underlying pathogenic mechanism of the allergic reaction is essential. Non-IgE-mediated reactions are less likely to fully respond to this therapy. Consequently, the mechanism of hypersensitivity reactions should ideally be substantiated by diagnostics in order to identify those patients that might benefit from the addition of omalizumab. Carboplatin-induced DHR are IgEmediated, as specific anti-carboplatin IgE antibodies can be detected in patients with DHR to carboplatin [9]. Iwamoto et al. nicely demonstrated in vitro an IgE-dependent mechanism in patients with carboplatin DHR [2]. The carboplatin reactivity was transferable when plasma of these patients was added to healthy control basophils, but could be almost completely blocked when cells were pre-treated with omalizumab.

For our patient, measurement of anti-carboplatin IgE was not available and a basophil activation test was unsuccessful probably due to the presence of low levels of omalizumab in the sample. Skin tests however repeatedly showed reactivity to carboplatin, which supports the presence of an IgE-mediated DHR.

Taken together, for patients with continued allergic reactions of established or strongly suspected IgE-mediated origin despite a desensitisation schedule including conventional anti-allergic medication, we recommend additional pre-treatment with one dose of omalizumab 1-3 weeks prior to each cycle of chemotherapy.

In conclusion, omalizumab can be a valuable addition to the allergologist's repertoire for desensitisation in case of patients suffering from adverse reactions suggestive of an IgE-mediated allergy.

\footnotetext{
Abbreviation

DHR: drug hypersensitivity reaction.

Acknowledgements

The authors would like to thank Annechien Lambeck and Laura Bungener for fruitful discussions and excellent laboratory assistance.

\section{Authors' contributions}

MJ was the treating oncologist of the patient, HOE and AvdV managed and supervised the desensitisation procedure; HD was responsible for drug delivery and (co-) developed the desensitisation schedule. HOE and AvdV wrote the article, AvdV drafted the figures, MJ and HD critically revised the manuscript. All authors read and approved the final manuscript.
} 


\section{Funding}

No funding was provided specifically for this study. H.N.G. Oude Elberink's institution has received consultancy fees from ALK-Abelló. H.N.G. Oude Elberink has received fees for delivering lectures from Chiesi, ALK-Abelló and Meda; has received consultancy fees from ALK-Abello; has received research support from Novartis, MEDA Pharma, Mead Johnson, ALK-Abello, Shire, and Chiesi; and has received payment for developing educational presentations from ALK-Abello. M. Jalving's institution has received consultancy fees from Merck, BMS, Novartis, PierreFabre, Tesaro, AstraZenica and fees for delivering lectures from Sanofi. The other authors declare that they have no relevant conflicts of interest.

\section{Availability of data and materials}

The datasets used and analysed during the current study are available from the corresponding author on reasonable request.

\section{Ethics approval and consent for publication}

Informed consent for publication was provided by the patient.

\section{Competing interests}

The authors declare that they have no competing interests.

\section{Author details}

${ }^{1}$ Department of Allergology and Internal Medicine, Internal address code AA21, University Medical Center Groningen, Hanzeplein 1, 9713 GZ Groningen, The Netherlands. ${ }^{2}$ Department of Medical Oncology, University Medical Center Groningen, Groningen, The Netherlands. ${ }^{3}$ Department of Clinical Pharmacy and Pharmacology, University Medical Center Groningen, Groningen, The Netherlands.

Received: 30 September 2019 Accepted: 12 January 2020

Published online: 29 January 2020

\section{References}

1. Markman M, Kennedy A, Webster K, Elson P, Peterson G, Kulp B, et al. Clinical features of hypersensitivity reactions to carboplatin. J Clin Oncol. 1999;17(4):1141.
2. Iwamoto T, Hirai H, Yamaguchi N, Kobayashi N, Sugimoto H, Tabata T, et al Carboplatin-induced severe hypersensitivity reaction: role of IgE-dependent basophil activation and FcepsilonRI. Cancer Sci. 2014;105(11):1472-9.

3. Castells MC, Tennant NM, Sloane DE, Hsu FI, Barrett NA, Hong DI, et al. Hypersensitivity reactions to chemotherapy: outcomes and safety of rapid desensitization in 413 cases. J Allergy Clin Immunol. 2008;122(3):574-80.

4. Ojaimi S, Harnett PR, Fulcher DA. Successful carboplatin desensitization by using omalizumab and paradoxical diminution of total lgE levels. J Allergy Clin Immunol In Pract. 2014;2(1):105-6.

5. Lang DM, Aronica MA, Maierson ES, Wang XF, Vasas DC, Hazen SL. Omalizumab can inhibit respiratory reaction during aspirin desensitization. Ann Allergy Asthma Immunol. 2018;121(1):98-104.

6. Yong PF, Malik R, Arif S, Peakman M, Amiel S, Ibrahim MA, et al. Rituximab and omalizumab in severe, refractory insulin allergy. N Engl J Med. 2009;360(10):1045-7.

7. Arroabarren E, Aznal E, Anda M, Sanchez-Valverde F. Anaphylaxis after Elosulfase A infusion: omalizumab as coadyuvant for enzyme replacement therapy desensitization. Pediatr Allergy Immunol. 2019;31:491.

8. Prieto-Garcia A, Noguerado B, Rojas P, Torrado I, Rodriguez-Fernandez A, Tornero P. Unexpected anaphylaxis after completing a desensitization protocol to oxaliplatin: successful adjuvant use of omalizumab. J Investig Allergol Clin Immunol. 2019;29(1):53-5.

9. Caiado J, Venemalm L, Pereira-Santos MC, Costa L, Barbosa MP, Castells M. Carboplatin-, oxaliplatin-, and cisplatin-specific IgE: cross-reactivity and value in the diagnosis of carboplatin and oxaliplatin allergy. J Allergy Clin Immunol Pract. 2013;1(5):494-500.

\section{Publisher's Note}

Springer Nature remains neutral with regard to jurisdictional claims in published maps and institutional affiliations.
Ready to submit your research? Choose BMC and benefit from:

- fast, convenient online submission

- thorough peer review by experienced researchers in your field

- rapid publication on acceptance

- support for research data, including large and complex data types

- gold Open Access which fosters wider collaboration and increased citations

- maximum visibility for your research: over $100 \mathrm{M}$ website views per year

At BMC, research is always in progress.

Learn more biomedcentral.com/submissions 